TecnoLógicas

ISSN-p 0123-7799

ISSN-e 2256-5337

Vol. 23, No. 48, pp. 83-98

Mayo-agosto de 2020

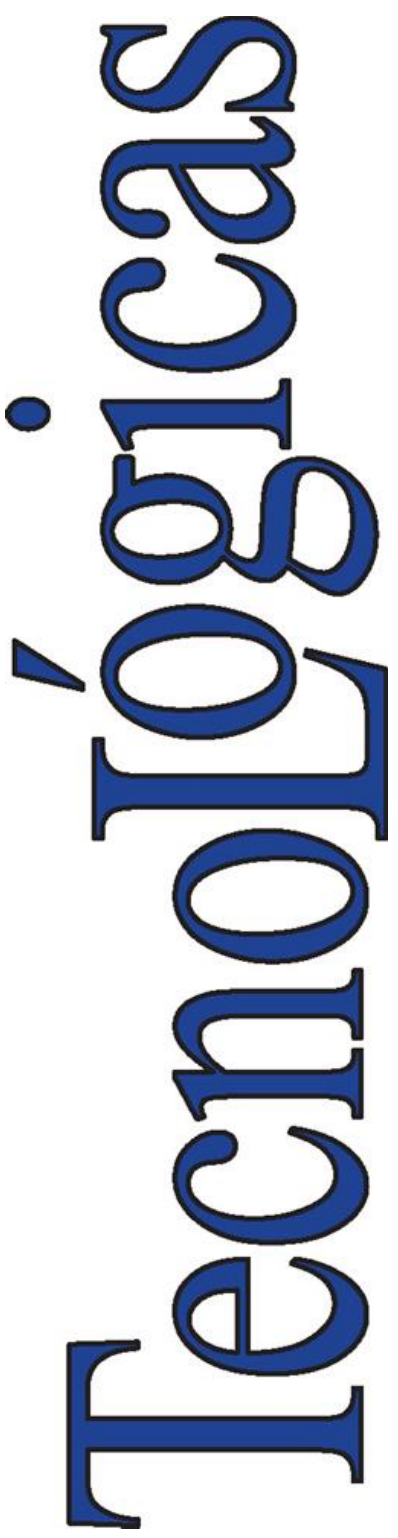

(C) Instituto Tecnológico Metropolitano Este trabajo está licenciado bajo una Licencia Internacional Creative Commons Atribución (CC BY-NC-SA)

\section{Optimization of the Tensile Properties of Polymeric Matrix Composites Reinforced with Magnetite Particles by Experimental Design}

\section{Optimización de las propiedades de tracción de compuestos de matriz polimérica reforzada con partículas de magnetita por diseño experimental}

\author{
Luis Ángel Lara-González(D) 1 \\ Wilmar Guillermo-Rodríguez(D)2 \\ Yaneth Pineda-Triana (D) 3 \\ Gabriel Peña-Rodríguez (D) 4 \\ Hugo Felipe Salazar(D) 5
}

Recibido: 16 de septiembre de 2019

Aceptado: 19 de marzo de 2020

Cómo citar / How to cite

L. A. Lara-González, W. G. Rodríguez, Y. Pineda-Triana, G. PeñaRodríguez, H. F. Salazar, "Optimization of the Tensile Properties of Polymeric Matrix Composites Reinforced with Magnetite Particles by Experimental Design,” TecnoLógicas, vol. 23, no. 48, pp. 83-98, 2020.

https://doi.org/10.22430/22565337.1499

1 PhD. in Materials Science, Department Mine Engineering, Universidad Pedagógica y Tecnológica de Colombia, TunjaColombia, luisangel.lara@uptc.edu.co

2 MSc. in Engineering, Department Industrial Engineering, Universidad Pedagógica y Tecnológica de Colombia, TunjaColombia,wilmar.rodriguez@uptc.edu.co

3 PhD. in Mechanic Engineering and Materials, INCITEMA, Universidad Pedagógica y Tecnológica de Colombia, TunjaColombia, yaneth.pineda@uptc.edu.co

4 PhD. in Materials Science, GIFIMAC Research Group, Universidad Francisco de Paula Santander, Cúcuta-Colombia, gabrielpr@ufps.edu.co

5 MSc. in Industrial Engineering, Department Industrial Engineering, Universidad Pedagógica y Tecnológica de Colombia, Tunja-Colombia, hugo.salazar@uptc.edu.co 


\section{Abstract}

A full-factorial $3^{3}$ experiment was used in this study to determine the optimal values of the tensile properties of three composite materials manufactured based on three polymeric resins: Derakane Momentum epoxy vinyl ester based on bisphenol-A (DM-411), polyester based on terephthalic acid (P115-A), and isophthalic polyester (P2000). Such materials were reinforced with magnetite powders at concentrations of 10,20, and $30 \mathrm{wt} \%$, and the particle sizes were classified with three sieves: \#200 (46-75 $\mu \mathrm{m})$, \#325 (26-45 $\mu \mathrm{m})$, and \#500 (0-25 $\mu \mathrm{m})$. The compounds were manufactured using the hand lay-up method at room temperature in accordance with ASTM D638-14 for M1-type specimens. A tensile test was conducted on a universal Microtest EM2/300/FR machine at a test speed of $5 \pm 25 \%$ $\mathrm{mm} / \mathrm{min}$ using an Epsilon extensometer calibrated in accordance with the ASTM E83 standard at $20 \pm 2{ }^{\circ} \mathrm{C}$. The magnetite powders and compound morphology were studied by Scanning Electron Microscopy. The mechanical properties of the compounds and the optimal response found by Analysis of Variance (ANOVA) and Response Surface Methodology (RSM) are also reported. The best response to the mechanical stimuli occurs with the composite material prepared with the epoxy vinyl ester resin DM-411, a concentration of $29.4 \%$ of magnetite $\left(\mathrm{Fe}_{3} \mathrm{O}_{4}\right)$, a particle size of 58.5 microns, and a 200 sieve.

\section{Keywords}

Tensile properties, Design Of Experiments, Magnetite, Composite, Response Surface Methodology.

\section{Resumen}

Un diseño factorial completo de $3^{3}$ fue desarrollado con el fin de determinar los valores óptimos en las propiedades de tracción de tres tipos de materiales compuestos fabricados a base de resinas poliméricas epoxy-vinylester (DM-411) base bisfenol-A, poliéster (P115-A) base de ácido tereftálico, y poliéster (P2000) base de ácido isoftálico, reforzados con polvos de magnetita en concentraciones de 10, 20 y $30 \%$ porcentaje en peso (Wt) con tres tamaños diferentes de partícula en el relleno, tamices \#200 (46-75 $\mu \mathrm{m})$, \#325 (26-45 $\mu \mathrm{m})$ у \#500 (0$25 \mu \mathrm{m})$. Los compuestos se fabricaron utilizando el método de moldeo manual a temperatura ambiente, según ASTM D638-14 para muestras de tipo M1. Los ensayos de tracción se realizaron en una máquina universal microtest EM2/300/FR a una velocidad de prueba de $5 \times 25 \% \mathrm{~mm} / \mathrm{min}$, utilizando un extensómetro Epsilon calibrado de acuerdo con la norma ASTM E83 a $20^{\circ} \mathrm{C}$. Los polvos de magnetita y la morfología de los materiales compuestos se estudiaron mediante microscopía electrónica de barrido. Se reportan las propiedades mecánicas de los compuestos y la respuesta óptima encontrada por análisis de varianza (ANOVA) y superficies de respuesta (RSM). La mejor respuesta a los estímulos mecánicos se produce con el material compuesto fabricado a base de resina epoxi -vinilester DM-411, con una concentración media de $29,4 \%$ de magnetita $\mathrm{Fe}_{3} \mathrm{O}_{4}$ y tamaño medio de partícula de 58,5 micras la cual corresponde a un tamiz 200.

\section{Palabras clave}

Propiedades de tensión, Diseño de experimento, Magnetita, Composites, Metodología de la superficie de respuesta. 


\section{INTRODUCTION}

Composite materials consist of two or more phases that form a single material known as composite [1]. Composites are classified based on the reinforcement material they use and their matrix, which can be metallic, polymeric, or ceramic.

Polymer composites have been widely used in various engineering and industrial applications due to their low fabrication cost, high strength, and high flexural and tensile strength [2].

Composite materials filled with particles have an isotropic behavior and high thermal conductivity when the particles are metallic or ceramic [3].

To improve the mechanical response of this type of composites, different types of filling materials have been used, such as silica-alumina [4]; aluminum [5]; carbon, graphite, and graphene fibers [6]; aluminum, nickel, or silver nitrides [7]; calcium carbonate [8]; natural reinforcements such as mallow [9]; lignocellulose [10]; and hard and soft ferrites like the magnetite [11]. Although the term filler is an unattractive name for these particles [2], it is important to emphasize the fundamental role they play in the processability of composite materials [12] and their response to thermal, mechanical, electrical, magnetic, and optical stimuli, among others [13]. Therefore, they are known as functional fillers [14], and each type of filler provides unique properties to the specific material used as matrix.

Consequently, the studies in this field have focused on evaluating the behavior of the so-called hard composites [15], finding changes in their thermal, mechanical, magnetic, and electrical properties [16] and specific applications through the incorporation of magnetic fillers, for the manufacture of ferrite cores, electromagnetic shielding [17], transducers [18], and in some biomedical applications like drug delivery, organs tagging and others[19].
Functional fillers such as magnetite are important in the manufacture of hard composite materials, since they are an abundant, economical, and easy to achieve due to the plenty number of mines found throughout Colombia, mainly those that are located in Huila and Cundinamarca [20].

The Design Of Experiments (DOE) can be implemented to develop new materials and applications using optimal mixtures to be evaluated, thus reducing the study population [21]. Vankanti et al. [22] indicated that it is possible to determine changes in material properties from mathematical models and DOE in accordance with the variation of several factors of the filling materials (such as concentrations, treatment time, and particle orientation). As a result, they obtained optimal response values.

In this study, DOE was used to find the optimal values of the mechanical properties of composites of epoxy vinyl ester and isophthalic and terephthalic polyester reinforced with particles of magnetite $\left(\mathrm{Fe}_{3} \mathrm{O}_{4}\right)$ of varying sizes and concentrations regarding the matrix.

\section{MATERIALS AND METHOD}

A $3^{3}$ full-factorial design was constructed considering three factors and three levels by factor: type of polymer (Pi), particle size (Ti), and percentage of the filler by weight \% (Wti). This study considered two replicas of the model, which involved 27 samples for each DOE. The levels of each factor are shown in Table 1.

The statistical analysis methods adopted here to study the mechanical responses of the composite materials, were Analysis of Variance (ANOVA) and normality tests using Minitab $18 \AA$ and Design-Expert $11 \AA$. Moreover, the optimization of the model was obtained by applying the Response Surface Methodology (RSM) employing the simultaneous multiple response technique in DesignExpert $11 \circledR$. 
Optimization of the Tensile Properties of Polymeric Matrix Composites Reinforced with Magnetite Particles by Experimental Design

Table 1. Factors and levels of experiments. Source: Created by the authors.

\begin{tabular}{llll}
\hline Levels & Low $(-1)$ & Medium $(0)$ & High $(1)$ \\
\hline Polymer $(\mathrm{Pi})$ & DM411 (P1) & P2000 (P2) & P115A (P3) \\
Filler \% (Wti) & 10 & 20 & 30 \\
Size $(\mathrm{Ti})$ & $19 \mu \mathrm{m}$ & $44 \mu \mathrm{m}$ & $59 \mu \mathrm{m}$ \\
\hline
\end{tabular}

\subsection{Materials}

Magnetite powders, supplied by Green Magnetite S.A. reference G-Mag $A \AA$, with a density of $5100 \mathrm{~kg} / \mathrm{m}^{3}$ and a particle size of less than $75 \mu \mathrm{m}$, were used as precursors for the preparation of the compounds. The matrices were made of three types of polymers: Derakane Momentum epoxy vinyl ester based on bisphenol-A (DM-411), with a density of $1046 \mathrm{~kg} / \mathrm{m} 3$ (referred hereinafter as "P1"); polyester based on terephthalic acid (P115-A), with a density of $1148 \mathrm{~kg} / \mathrm{m}^{3}$, supplied by Novasuin SAS (referred hereinafter as "P2"); and isophthalic polyester (P2000), with a density of $1018 \mathrm{~kg} / \mathrm{m}^{3}$, supplied by Industria Colombiana de Resinas (referred hereinafter as "P3"). SuperCat S-960®, supplied by NovaSuin, was used as the catalyst in concentrations of $1 \%$ by weight in accordance with supplier specifications.

\subsection{Composite manufacturing}

Initially, the $\mathrm{Fe}_{3} \mathrm{O}_{4}$ magnetite powders were screened with a 200 sieve $(46-75 \mu \mathrm{m})$.

The content was sieved again with a 325 sieve $(26-45 \mu \mathrm{m})$, and the residual was stored. A final screening with a 500 sieve was carried out $(0-25 \mu \mathrm{m})$. The residual and content were identified as $\mathrm{T} 1, \mathrm{~T} 2$, and T3, respectively. Ro-Tap ${ }^{\circledR}$ equipment was used for 45 minutes, and, as a result, 1000 grams of magnetite were obtained for each sieve. The compounds were manufactured using the manual casting method at room temperature, in accordance with ASTM D638-14 for M1-type specimens.

The manufacturing process started by weighing 50 grams of each resin at a room temperature of $17{ }^{\circ} \mathrm{C}$. The weight concentration of magnetite in the polymer matrix was determined in accordance with Ngo, Jeon, and Byon [23] and Hussain et al. [24], taking 10, 20, and $30 \%$ by weight.

Taking these parameters into account, 5,10 , and $20 \mathrm{~g}$ of magnetite were weighed for each particle size. Subsequently, the filler was added to each resin by stirring the blend for 5 minutes at a frequency of 100 rpm using a DLAB OS20-S head stirrer.

After the mixture was homogenized, a $1 \%$ catalyst (SuperCat S-960®) was added, stirring for approximately 1 minute.

The mixture was then poured into acrylic molds. The composite samples were cured at room temperature for $24 \mathrm{~h}$.

\subsection{Compound testing and characterization}

The tensile test was performed on a universal Microtest EM2/300/FR machine at a test speed of $5 \pm 25 \% \mathrm{~mm} / \mathrm{min}$, using an Epsilon extensometer calibrated in accordance with the ASTM E83 standard at $20 \pm 2{ }^{\circ} \mathrm{C}$. The magnetite powders and the compound morphology were studied using Scanning Electron Microscopy (Zeiss Evo 10). Each sample was previously coated with palladium gold by sputtering (Quorum Q150 R-ES), and the microanalysis was conducted via scattered energy spectroscopy using an SDD-Apollo X series probe.

The magnetite particles were perfectly and uniformly integrated into the polymer matrix, preserving the uniformity in the medium size and a wide range of irregularly shaped particle sizes with a low 
aspect ratio. This matches the observations of Weidenfeller, Höfer, and Schilling [25] and Garzón et al. [11]. The micrographic analysis was carried out using ImageJ software to extract information about the size of each particle. This information was statistically analyzed with Minitab $18 \AA$ software. The results reveal a mean particle size of $21.48 \mu \mathrm{m}$ with the 200 sieve with a standard deviation of $13.43 \mu \mathrm{m}$ and a maximum value of $58.99 \mathrm{\mu m}$. The mean value with the 325 sieve was $16.74 \mu \mathrm{m}$, with a standard deviation of $8.43 \mu \mathrm{m}$, and a maximum size of $44 \mu \mathrm{m}$.

An average value of $8.36 \mu \mathrm{m}$ was found with the 500 sieve, with a standard deviation of $3.68 \mu \mathrm{m}$ and a maximum value of $18.62 \mu \mathrm{m}$. Similar results were reported by Peña et al. [26].

\section{RESULTS AND DISCUSSIONS}

\subsection{Microstructural analysis of magnetite}

The effective particle size produced by the T1, T2, and T3 sieves was assessed by means of a micrographic analysis. Fig. 1 shows the evolution of particle size as the concentration of magnetite increases (10, 20 , and $30 \mathrm{wt} \%$ ) with each of the sieves (T1: \#200, T2: \#325, and T3: \#500).
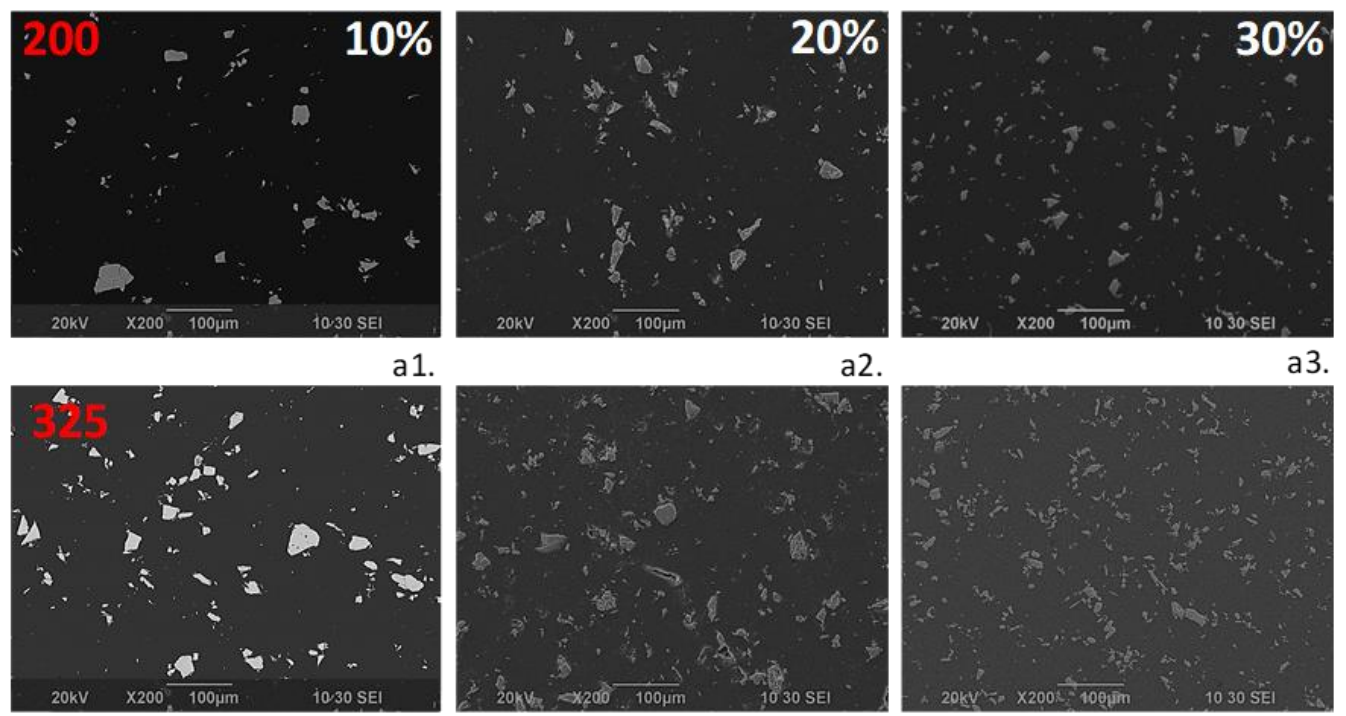

.

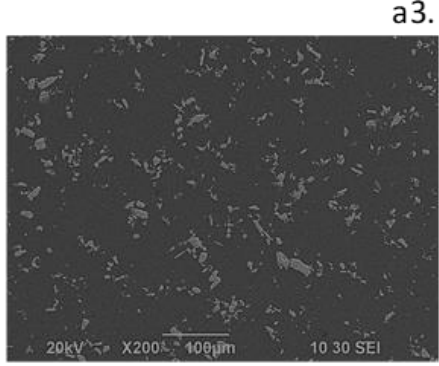

b1.

b2.

b3.
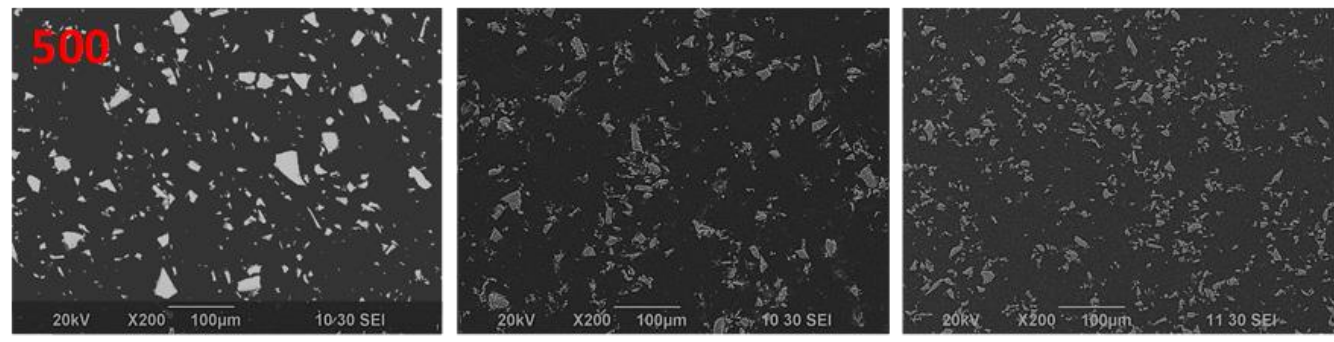

c1.

c2.

c3.

Fig. 1. Size distribution of magnetite particles $\left(\mathrm{Fe}_{3} \mathrm{O}_{4}\right)$ classified with (a) 200 sieve, (b) 325 sieve, and (c) 500 sieve in concentrations of 10,20 , and $30 \mathrm{wt} \%$ by weight. Source: Created by the authors. 


\subsection{Tensile response}

Based on the results obtained in the tensile test of the standardized test pieces (M1-type as per ASTM D638-14 standard), the main mechanical properties of the composite materials made in this study from polymer resins reinforced with magnetite powders are reported in Tables 2 to 4 . The granulometry and concentration of the powder precursor were varied $(10,20$, and $30 \%$ by weight) depending on the volume of resin used in each case.

Fig. 2 shows the behavior of the modulus of elasticity of the composite
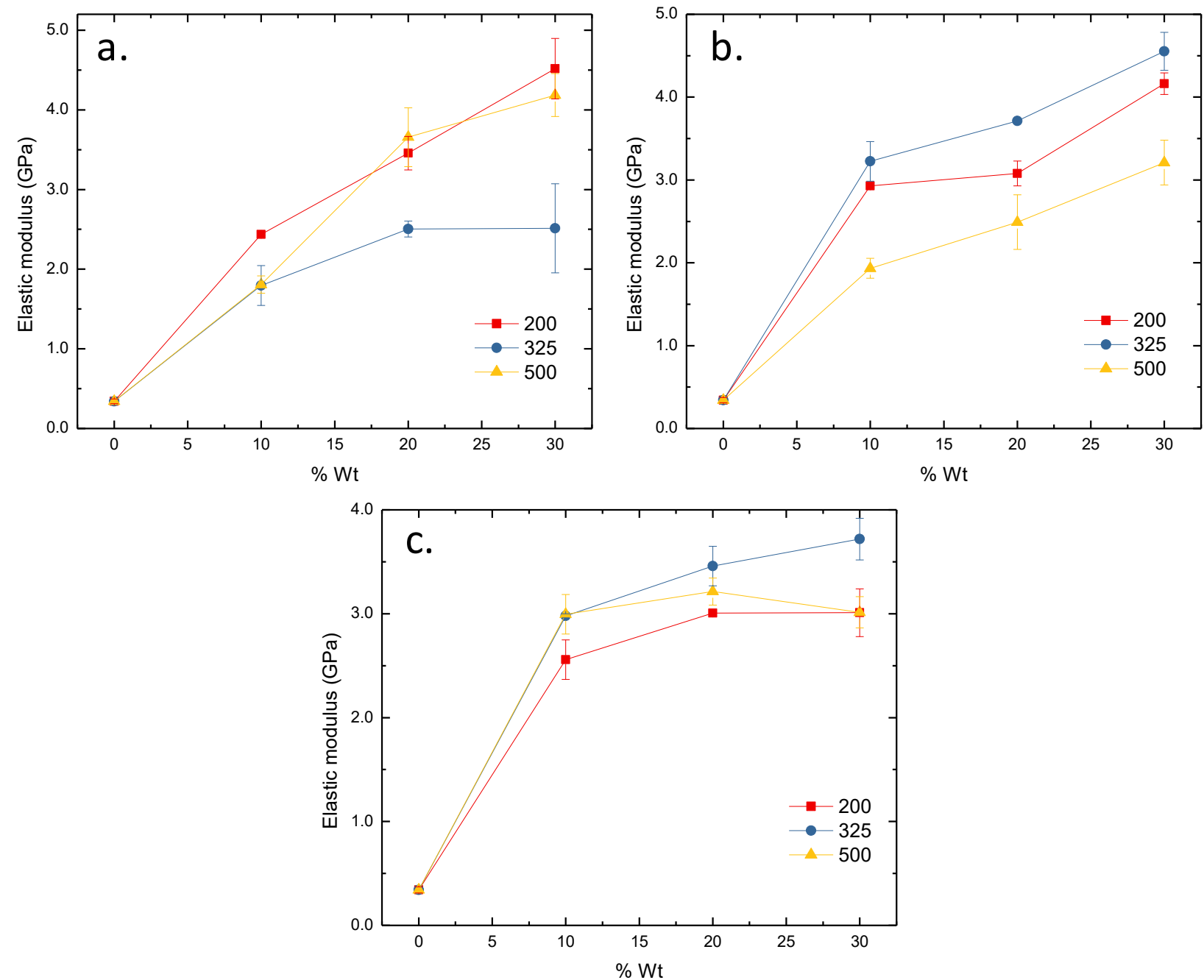

Fig. 2. Elastic Modulus obtained in the tensile test of compounds made with (a) Derakane Momentum epoxy vinyl ester based on bisphenol-A (DM-411), (b) isophthalic polyester (P2000), and (c) polyester based on terephthalic acid (P115-A) with variations in particle size and concentration of magnetite $\left(\mathrm{Fe}_{3} \mathrm{O}_{4}\right)$ in percentages of 10, 20, and $30 \mathrm{wt} \%$. Source: Created by the authors. 
Optimization of the Tensile Properties of Polymeric Matrix Composites Reinforced with Magnetite Particles by Experimental Design

Table 2. Mechanical properties of the composite materials made with the DM411 epoxy vinyl ester resin Source: Created by the authors.

\begin{tabular}{cccccc}
\hline Magnetite $\%$ & Sieve & $\rho\left(\mathrm{g} / \mathrm{m}^{3}\right)$ & Tensile strength $(\mathrm{MPa})$ & Deformation $(\%)$ & $E(\mathrm{GPa})$ \\
\hline 0 & 0 & $1.15 \pm 0.04$ & $22.88 \pm 0.63$ & $0.73 \pm 0.02$ & $0.342 \pm 0.03$ \\
\hline \multirow{2}{*}{10} & 200 & $1.68 \pm 0.67$ & $49.92 \pm 12.73$ & $1.15 \pm 0.32$ & $2.438 \pm 0.02$ \\
& 325 & $1.03 \pm 0.77$ & $47.46 \pm 6.94$ & $0.78 \pm 0.37$ & $1.795 \pm 0.25$ \\
& 500 & $1.44 \pm 0.57$ & $40.92 \pm 9.26$ & $1.78 \pm 0.32$ & $1.808 \pm 0.11$ \\
\hline \multirow{2}{*}{20} & 200 & $1.41 \pm 0.36$ & $56.47 \pm 8.10$ & $2.15 \pm 0.22$ & $3.457 \pm 0.21$ \\
& 325 & $1.07 \pm 0.40$ & $49.10 \pm 9.26$ & $1.89 \pm 0.23$ & $2.505 \pm 0.10$ \\
& 500 & $1.35 \pm 0.49$ & $48.28 \pm 10.42$ & $1.65 \pm 0.96$ & $3.657 \pm 0.37$ \\
\hline \multirow{2}{*}{30} & 200 & $1.06 \pm 0.61$ & $58.10 \pm 10.42$ & $2.28 \pm 0.19$ & $4.518 \pm 0.38$ \\
& 325 & $1.16 \pm 0.55$ & $56.47 \pm 3.47$ & $2.90 \pm 0.32$ & $2.513 \pm 0.56$ \\
& 500 & $1.54 \pm 0.38$ & $52.37 \pm 11.57$ & & $4.186 \pm 0.27$ \\
\hline
\end{tabular}

Table 3. Mechanical properties of the composite materials made with the P2000 isophthalic polyester resin Source: Created by the authors.

\begin{tabular}{cccccc}
\hline Magnetite $\%$ & Sieve & $\rho\left(\mathrm{g} / \mathrm{m}^{3}\right)$ & Tensile strength $(\mathrm{MPa})$ & Deformation $(\%)$ & $E(\mathrm{GPa})$ \\
\hline \multirow{2}{*}{10} & 200 & $1.15 \pm 0.67$ & $41.74 \pm 12.73$ & $1.30 \pm 0.37$ & $2.928 \pm 0.02$ \\
& 325 & $0.78 \pm 0.77$ & $47.46 \pm 25.46$ & $1.29 \pm 0.18$ & $3.225 \pm 0.24$ \\
& 500 & $1.08 \pm 0.57$ & $27.82 \pm 9.26$ & $1.49 \pm 0.37$ & $1.934 \pm 0.12$ \\
\hline \multirow{2}{*}{20} & 200 & $2.15 \pm 0.36$ & $42.55 \pm 11.57$ & $1.27 \pm 0.29$ & $3.080 \pm 0.15$ \\
& 325 & $1.90 \pm 0.40$ & $49.92 \pm 10.41$ & $1.64 \pm 0.12$ & $3.713 \pm 0.02$ \\
& 500 & $2.11 \pm 0.49$ & $33.55 \pm 10.42$ & $1.62 \pm 0.31$ & $2.491 \pm 0.33$ \\
\hline \multirow{2}{*}{30} & 200 & $2.23 \pm 0.61$ & $54.01 \pm 11.57$ & $1.30 \pm 0.29$ & $4.164 \pm 0.13$ \\
& 325 & $1.89 \pm 0.55$ & $52.59 \pm 15.77$ & $2.32 \pm 0.08$ & $4.554 \pm 0.23$ \\
& 500 & $1.65 \pm 0.38$ & $53.19 \pm 15.04$ & $1.80 \pm 0.20$ & $3.210 \pm 0.27$ \\
\hline
\end{tabular}

Table 4. Mechanical properties of the composite materials made with the P115A terephthalic polyester resin Source: Created by the authors.

\begin{tabular}{cccccc}
\hline Magnetite $\%$ & Sieve & $\rho(\mathrm{g} / \mathrm{m} 3)$ & Tensile strength $(\mathrm{MPa})$ & Deformation $(\%)$ & $E(\mathrm{GPa})$ \\
\hline \multirow{2}{*}{10} & 200 & $1.30 \pm 0.56$ & $40.99 \pm 7.05$ & $1.61 \pm 0.02$ & $2.557 \pm 0.19$ \\
& 325 & $1.29 \pm 0.42$ & $26.56 \pm 3.11$ & $1.34 \pm 0.14$ & $2.980 \pm 0.02$ \\
& 500 & $0.90 \pm 0.53$ & $41.26 \pm 4.03$ & $1.35 \pm 0.19$ & $2.995 \pm 0.19$ \\
\hline \multirow{2}{*}{20} & 200 & $1.27 \pm 0.18$ & $36.23 \pm 8.63$ & $1.41 \pm 0.27$ & $3.007 \pm 0.02$ \\
& 325 & $1.64 \pm 0.34$ & $29.45 \pm 3.99$ & $1.67 \pm 0.32$ & $3.459 \pm 0.19$ \\
& 500 & $1.80 \pm 0.35$ & $42.84 \pm 6.47$ & $1.40 \pm 0.52$ & $3.213 \pm 0.13$ \\
\hline \multirow{2}{*}{30} & 200 & $1.62 \pm 0.38$ & $29.94 \pm 6.23$ & $1.68 \pm 0.41$ & $3.001 \pm 0.23$ \\
& 325 & $2.32 \pm 0.79$ & $45.94 \pm 1.31$ & $1.16 \pm 0.24$ & $3.719 \pm 0.20$ \\
& 500 & $1.49 \pm 0.50$ & $45.73 \pm 14.55$ & $1.43 \pm 0.01$ & $3.013 \pm 0.15$ \\
\hline
\end{tabular}




\subsection{Analysis and adjustment of model responses by DOE}

The objective of our Design of Experiments (DOE) was to determine the optimal values of the mechanical responses of composite materials made from three different polymer resins $(\mathrm{Pi})$ at three different filler concentration percentages in the resins (Filler \%, Wti) and three granulometries (size, Ti).

Considering the factors described above and their levels, a multiple regression analysis was performed to develop the mathematical model and optimize the responses. The data obtained experimentally were adjusted considering the mathematical model defined in (1), where yijk is the response variable generated from the previously described fixed factors $\mathrm{i}, \mathrm{j}$, and $\mathrm{k}$; $\mathrm{i}$, the effect of the polymer type on the polymer matrix; $B j$, the $\%$ by weight of the particles in the reinforcement; and $\gamma \mathrm{k}$, the effect of particle size. The uncontrollable factors that affect the response variable are also included in the model as follows: TB (interaction between factors 1 and 2), TY (interaction between factors 1 and 3 ), BY (interaction between factors 2 and 3 ), TBY (interaction between the three factors), and eijkl (standard error of the model). An ANOVA test was implemented to determine the significance and impact of the fixed factors on the response variables in the model, i.e., tensile strength (TS), modulus of elasticity (E), elongation percentage $\left(\begin{array}{ll}\% & \varepsilon\end{array}\right)$, and density $(\rho)$.

\subsubsection{ANOVA}

The significance of the fixed factors involved in the DOE model described above was evaluated using Design-Expert Pro-11.

Each of the input parameters in the model was adjusted using ANOVA, which compares the $p$-values obtained for each of them to a determined significance value; in this case, $\mathrm{P}=0.05$ (Table 5, Table 6, Table 7 and Table 8).

Table 5 shows the effect of the fixed factors polymer $(\mathrm{Pi})$, size $(\mathrm{Ti})$, and filler \% (Wti) on the tensile strength (TS) of the composite materials. An F-value of 8.06 in tensile strength is significant if the interactions of each one of those fixed factors with the response variable (1) are compared, with only a $0.02 \%$ chance that the F-value is due to errors.

Therefore, the ANOVA test provided an adjusted model from which it can be inferred that the type of polymer $(\mathrm{Pi})$ and the concentration of magnetite $\mathrm{Fe}_{3} \mathrm{O}_{4}$ (i.e., filler \% or Wti) significantly influence the outcome.

$$
y_{i j k l}=\mu+\tau_{i}+\beta_{j}+y_{k}+(\tau \beta)_{i j}+(\tau \gamma)_{i k}+(\beta \gamma)_{j k}+(\tau \beta \gamma)_{i j k}+\varepsilon_{i j k l}
$$

Table 5. ANOVA test for tensile strength (TS). Source: Created by the authors.

\begin{tabular}{lcccccc}
\hline Source & Sum of Squares & $d f$ & Mean Square & F-value & $p$-value & Contribution \\
\hline Model & 1528.21 & 6 & 254.7 & 8.06 & 0.0002 & significant \\
A- Polymer (Pi) & 809.82 & 2 & 404.91 & 12.81 & 0.0003 \\
B- Filler \% (Wti) & 398.51 & 1 & 398.51 & 12.61 & 0.002 \\
C- Size (Ti) & 33.18 & 1 & 33.18 & 1.05 & 0.3177 \\
AC & 286.69 & 2 & 143.35 & 4.54 & 0.0237 \\
Residual & 631.98 & 20 & 31.6 & & \\
Cor total & 2160.19 & 26 & & & \\
\hline
\end{tabular}


Optimization of the Tensile Properties of Polymeric Matrix Composites Reinforced with Magnetite Particles by Experimental Design

Table 6. ANOVA test for elastic modulus. Source: Created by the authors.

\begin{tabular}{lcccccc}
\hline Source & Sum of Squares & $d f$ & Mean Square & F-value & p-value & Contribution \\
\hline Model & $7 . \mathrm{E}+06$ & 4 & $2 . \mathrm{E}+06$ & 4.59 & 0.0076 & significant \\
A- Polymer (Pi) & $3 . \mathrm{E}+05$ & 2 & $2 . \mathrm{E}+05$ & 0.458 & 0.6384 & \\
B- Filler \% (Wti) & $6 . \mathrm{E}+06$ & 1 & $6 . \mathrm{E}+06$ & 16.27 & 0.0006 \\
C- Size (Ti) & $4 . \mathrm{E}+05$ & 1 & $4 . \mathrm{E}+05$ & 1.16 & 0.2936 & \\
Residue & $8 . \mathrm{E}+06$ & 22 & $4 . \mathrm{E}+05$ & & & \\
Cor Total & $1 . \mathrm{E}+07$ & 26 & & & & \\
\hline
\end{tabular}

Table 7. ANOVA test for elongation (\% E). Source: Created by the authors.

\begin{tabular}{lcccccc}
\hline Source & Sum of Squares & $d f$ & Mean Square & F-value & p-value & Contribution \\
\hline Model & $2 . \mathrm{E}+00$ & 6 & $3 . \mathrm{E}-01$ & 3.62 & 0.0136 & significant \\
A- Polymer (Pi) & 0.3958 & 2 & 0.1979 & 2.36 & 0.1204 & 0.0049 \\
B- Filler \% (Wti) & 0.8407 & 1 & 0.8407 & 10.02 & 0.6645 \\
C- Size (Ti) & 0.0163 & 1 & 0.0163 & 0.1938 & 3.38 & 0.0542 \\
AB & 0.5681 & 2 & 0.2841 & & \\
Residue & 1.68 & 20 & 0.0839 & & & \\
Cor Total & 3.5 & 26 & & & & \\
\hline
\end{tabular}

Table 8. ANOVA test for density $(\rho)$. Source: Created by the authors.

\begin{tabular}{lcccccc}
\hline Source & Sum of Squares & $d f$ & Mean Square & F-value & p-value & Contribution \\
\hline Model & 2.51 & 6 & 0.4178 & 4.08 & 0.0078 & significant \\
A- Polymer (Pi) & 0.5751 & 2 & 0.2876 & 2.81 & 0.0841 & 0.0048 \\
B- \% Fill (Wti) & 1.03 & 1 & 1.03 & 10.08 & 0.7622 & \\
C- Size (Ti) & 0.0096 & 1 & 0.0096 & 0.0941 & 4.35 & \\
AB & 0.8902 & 2 & 0.4451 & & & \\
Residue & 2.05 & 20 & 0.1024 & & & \\
Cor Total & 4.55 & 26 & & & & \\
\hline
\end{tabular}

However, the interaction between the type of polymeric resin and the granulometry of the particles in the filler has an influence on the tensile strength of the composite materials, and, consequently, such interaction could become a control variable in the manufacturing process of the compounds.

Table 6 shows the results of the ANOVA test for the elastic modulus (E), which is a property derived from the effect that the applied force has on the crosssectional area of the composite material
[29]. Our DOE determined the behavior of this response variable as a function of the fixed factors; we found a $\mathrm{P}$ level of statistical significance of $0.2 \%$ of Filler \% (Wti) compared to the other two factors, which were not representative of the behavior of said response variable. This was a linear type of behavior, given the lack of interaction between the factors.

Variance analyses of the response variables elongation percentage $\left(\begin{array}{ll}\% & \varepsilon\end{array}\right)$ (Table 7) and density ( $\rho$ ) (Table 8 ) were performed. They produced values of 3.62 
and a probability of $0.8 \%$, and 4.17 and $0.07 \%$, respectively. This finding shows a high significance in all the cases.

The elongation $(\% \varepsilon)$ ) and density $(\rho)$ of the composite materials directly depend on the interaction between the type of polymer used as matrix and the percentage of filler in the polymer matrix.

\subsubsection{Normal probability plots of residuals}

The normality plot technique was used to determine if the data from the response variables in the model had a behavior adjusted to a normal distribution. These plots show residual data compared to expected ones [30]. Fig. 3 reveals that the residuals are plotted approximately along a straight line for each response variable, which shows no evidence of non-normality or unidentified variables. The results have a normal distribution as the plot is close to the expected line. Therefore, our design is balanced, and the residuals neither affect the normality of the model nor influence the results.

\section{TS}
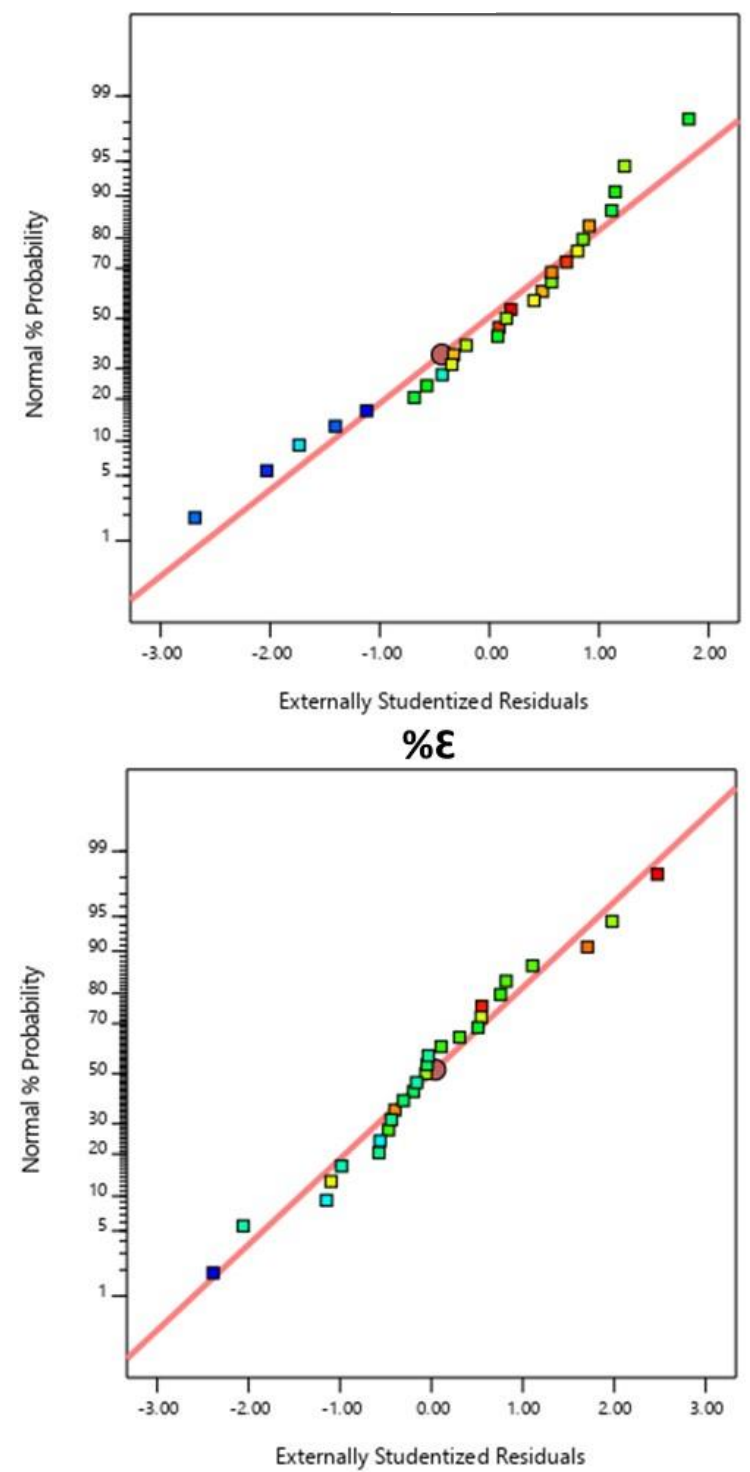

E

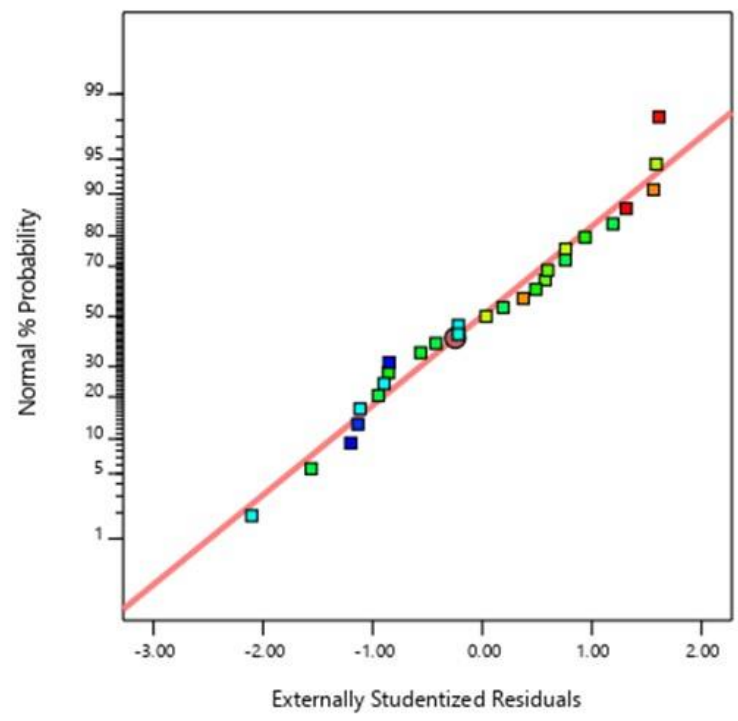

$\rho$

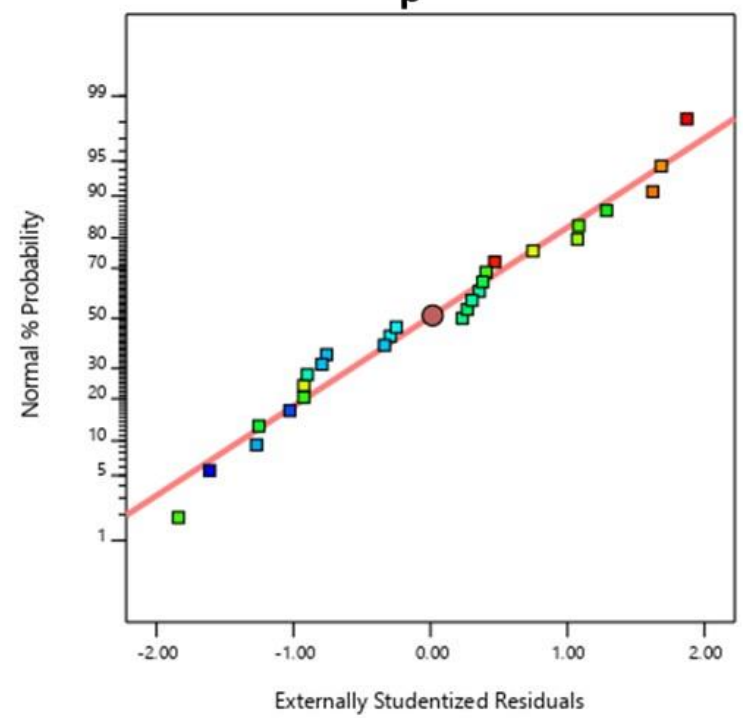

Fig. 3. Normal probability plots of residuals. Source: Created by the authors. 


\subsection{Optimization of the model by DOE}

Once the significance and normality of our model were verified, the response surfaces were characterized; for that purpose, the simultaneous consideration of multiple responses was used. Four models were constructed for each response (Fig.4).

The set of operating conditions that optimize all the answers, or at least keep them within the desired ranges, was identified.

Fig. 5a shows the contour graph of tensile strength. By increasing the concentration of the filler by $26 \%$ and with a particle size of 48 microns, a tensile strength of $55 \mathrm{MPa}$ was obtained.
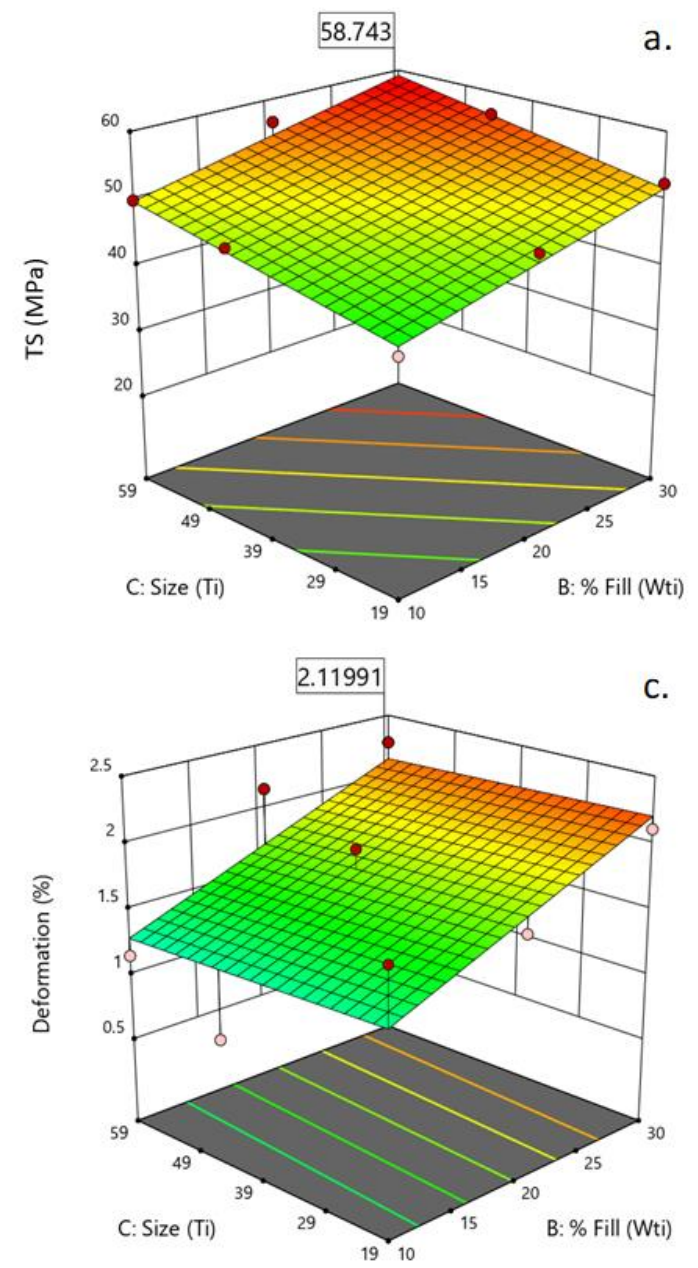

Fig. $5 b$ shows the evolution of the elasticity modulus, which increases by 200 $\mathrm{MPa}$ when the filler with a constant particle size of 39 microns was added.

By increasing the concentration of magnetite in the filling over $30 \%$, the response variable grows drastically depending on the particle size, which is approximately 57 microns. The elongation percentage increases linearly with the concentration at a mean particle size of 39 microns.

However, the density is independent of particle size and inversely proportional to the concentration; hence, the type of polymer positively influences the response of this variable (elongation percentage).
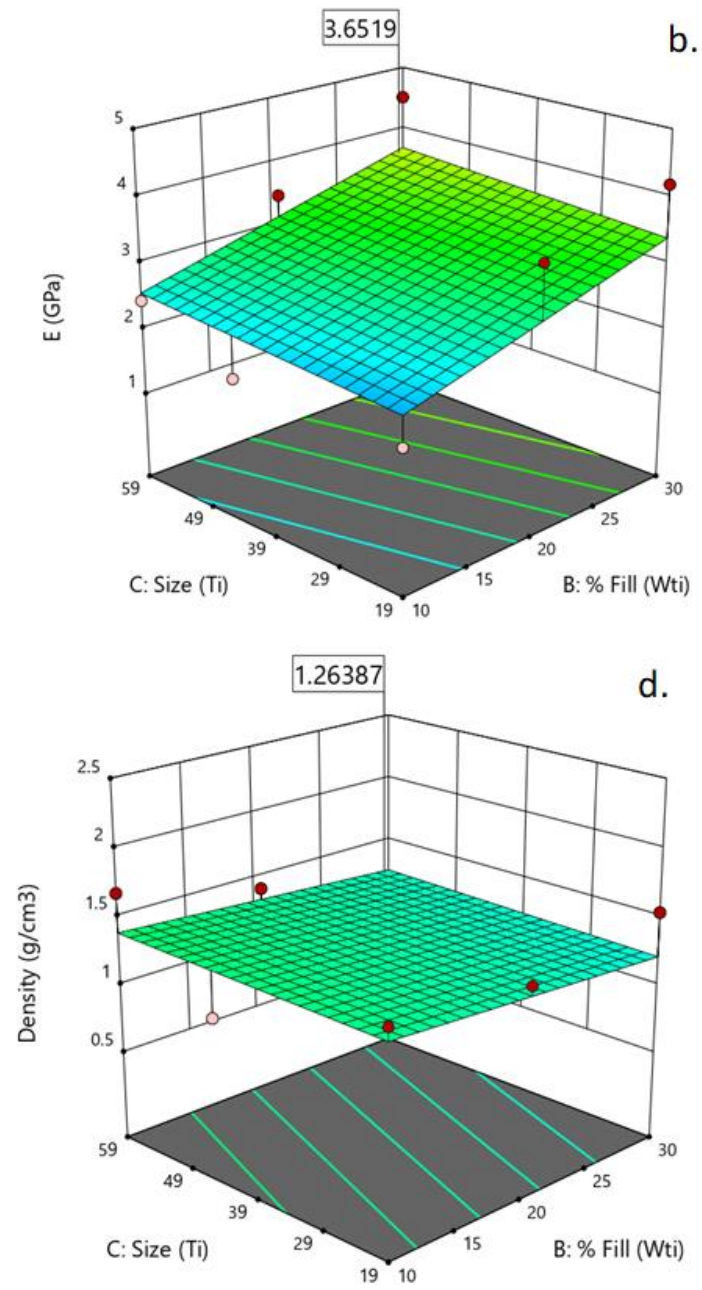

Fig. 4. RSM of (a) tensile strength (TS), (b) elasticity modulus (E), (c) elongation percentage $(\% \varepsilon)$, and $(d)$ density $(\rho)$. Source: Created by the authors. 

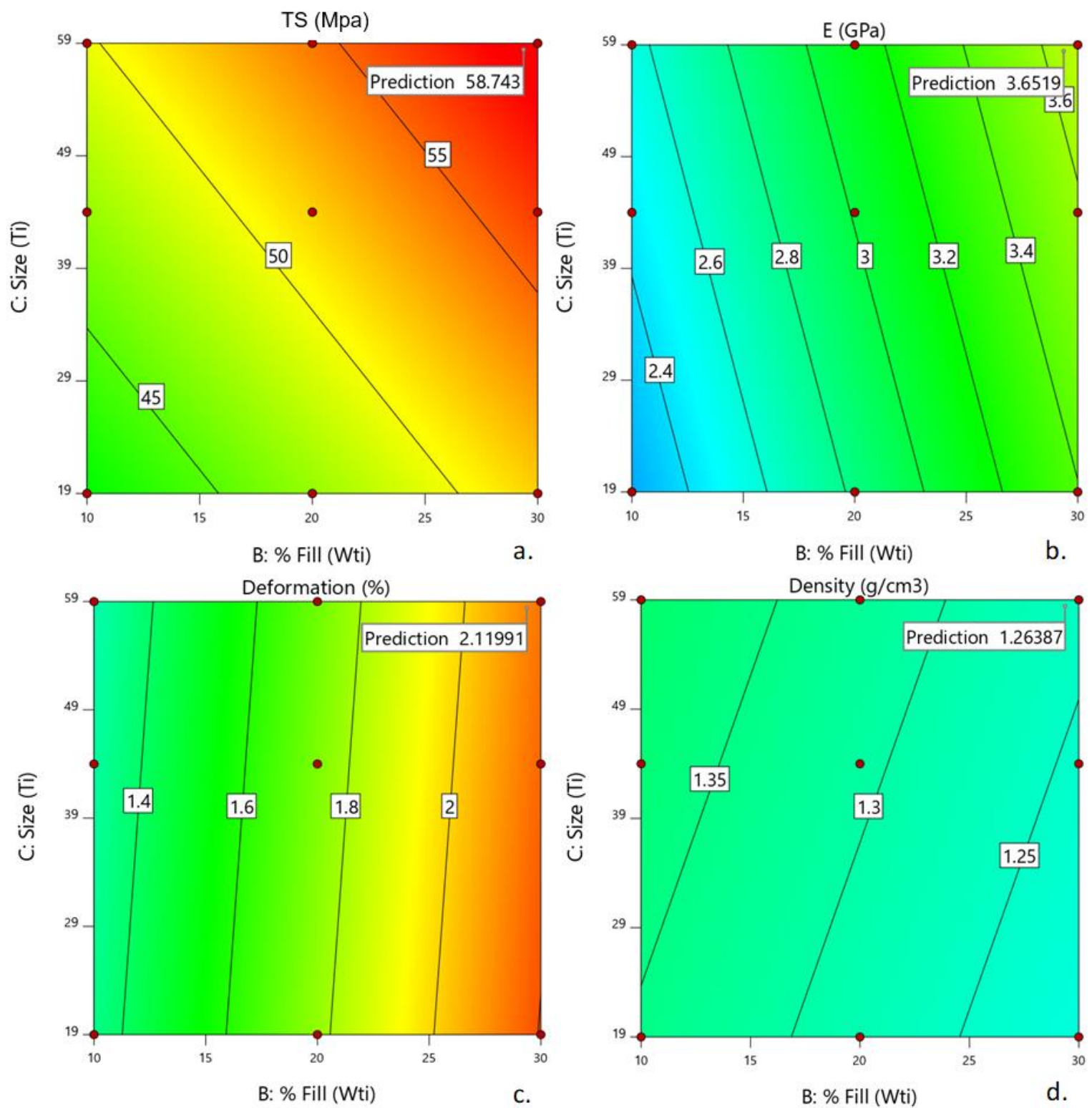

Fig. 5. RSM contour graphics of solutions to (a) tensile strength (RT), (b) modulus of elasticity (E), (c) elongation percentage $(\% \varepsilon)$, and $(d)$ density $(\rho)$. Source: Created by the authors.

To perform the optimization process and consider the behavior of the response surfaces, the constraints of the modelnamely, the factors polymer model (Pi), filler \% (Wti), and size (Ti)-were set within the range. The response variables modulus of elasticity (E), percentage of elongation $\left(\begin{array}{ll}\% & \varepsilon\end{array}\right)$, and density $(\rho)$ were calculated in said range. Finally, Tensile Strength (RT) was determined as an objective function in the maximization.
Table 9 summarizes the model restrictions that were entered into DesignExpert $1{ }^{\circledR}$ software. The latter found 87 solutions to the experimental model with $100 \%$ desirability, which indicates that the model restrictions are adequate.

Table 10 summarizes the first five solutions for the model. The best response to mechanical stimuli occurs with the composite material made with the Derakane Momentum epoxy vinyl ester based on bisphenol-A (DM-411), a 
concentration of $29.4 \%$ of magnetite $\left(\mathrm{Fe}_{3} \mathrm{O}_{4}\right)$, and a particle size of 58.5 microns. The 200 sieve produced a modulus of elasticity (E) of $3.652 \mathrm{GPa}$, a percentage of maximum deformation in the elongation \% $\varepsilon$ of $2.120 \%$, and a density of $1.264 \mathrm{~g} / \mathrm{cm}^{3}$.
To confirm the statistical data, Solution 1 was compared with the experimental values of four samples made of the material previously described. Table 11 presents the predicted values for the solutions with a good fit with the experimental results.

Table 9. Model restrictions. Source: Created by the authors.

\begin{tabular}{|c|c|c|c|c|c|c|}
\hline Name & Goal & Lower Limit & Upper Limit & Lower Weight & Upper Weight & Importance \\
\hline A: Polymer (Pi) & In range & $\mathrm{P} 1$ & P3 & 1 & 1 & 3 \\
\hline B: Filler \% (Wti) & In range & 10 & 30 & 1 & 1 & 3 \\
\hline C: Size (Ti) & In range & 19 & 59 & 1 & 1 & 3 \\
\hline $\mathrm{RT}$ & Maximize & 26.563 & 58.101 & 1 & 1 & 3 \\
\hline $\mathrm{E}$ & In range & 1.79534 & 4.55339 & 1 & 1 & 3 \\
\hline$\% \varepsilon$ & In range & 0.78 & 2.32 & 1 & 1 & 3 \\
\hline Density $(\rho)$ & In range & 0.78 & 2.32 & 1 & 1 & 3 \\
\hline
\end{tabular}

Table 10. Optimization results. Source: Created by the authors.

\begin{tabular}{ccccccccc}
\hline \multirow{2}{*}{ Solution } & Polymer (Pi) & Filler \%(Wti) & Size (Ti) & TS & $E$ & $\begin{array}{c}\text { Maximum } \\
\text { deformation }\end{array}$ & Density & Desirability \\
\hline $\mathbf{1}$ & $\mathbf{p 1}$ & $\mathbf{2 9 . 3 7 2}$ & $\mathbf{5 8 . 4 3 7}$ & $\mathbf{5 8 . 7 4 3}$ & $\mathbf{3 . 6 5 2}$ & $\mathbf{2 . 1 2 0}$ & $\mathbf{1 . 2 6 4}$ & $\mathbf{1}$ \\
2 & p1 & 29.486 & 58.660 & 58.838 & 3.660 & 2.124 & 1.263 & 1 \\
3 & p1 & 29.906 & 58.125 & 58.936 & 3.680 & 2.143 & 1.260 & 1 \\
4 & p1 & 29.674 & 54.298 & 58.111 & 3.638 & 2.139 & 1.257 & 1 \\
5 & P1 & 29.594 & 58.750 & 58.906 & 3.667 & 2.129 & 1.263 & 1 \\
\hline
\end{tabular}

Table 11. Comparison of predicted and experimental values. Source: Created by the authors.

\begin{tabular}{lccc}
\hline Response variable & Code & Predicted & Experimental \\
\hline Tensile strength $(\mathrm{MPa})$ & TS & 58.480 & $58.476 \pm 0.130$ \\
E $(\mathrm{GPa})$ & $\mathrm{E}$ & 3.636 & $3.6367 \pm 0.014$ \\
Deformation $(\%)$ & $\% \varepsilon$ & 2.112 & $2.1118 \pm 0.012$ \\
\hline
\end{tabular}

\section{CONCLUSION}

In conclusion, our model based on a $3^{3}$ full-factorial design can be used to determine the optimal values of the factors that maximize the response of composite materials subjected to mechanical stimuli.

The mechanical properties of composite materials made from three different types of polymer resins (namely, epoxy vinyl ester DM411, polyester isophthalic P2000, and polyester terephthalic P115A) were investigated. Such materials contained different concentrations of magnetite $\left(\mathrm{Fe}_{3} \mathrm{O}_{4}\right)$ in the functional filler and different particle sizes.

Through a complete $3^{3}$ DOE factorial design, it was possible to determine the influence of three fixed factors on the mechanical properties of the manufactured compounds: Tensile Strength (TS), Elasticity modulus (E), maximum deformation in the elongation $(\% \varepsilon)$, and density $(\rho)$. The significance of the fixed factors on the response variables the model was established, determining the operating 
and work parameters that allowed the optimization of the maximum tensile strength (TS) of the material manufactured with Derakane Momentum epoxy vinyl ester based on bisphenol-A (DM-411), a concentration of $28.6 \%$ magnetite $\left(\mathrm{Fe}_{3} \mathrm{O}_{4}\right)$ in the filler, and a particle size of 58.94 microns. The elasticity module (E) of this material was $3611.67 \mathrm{MPa}$; its percentage of maximum deformation in elongation \% $\mathcal{E}, 2.086 \%$; and its density, $1.272 \mathrm{~g} / \mathrm{cm}^{3}$.

The composite materials showed an increase in stiffness compared to the behavior of pure polyester and exhibited a relatively high tensile stress, reaching a tension above $58.71 \mathrm{MPa}$ with a deformation of $0.2 \%$ at the creep limit.

In conclusion, such material exhibits anisotropic behavior, and its modulus of elasticity increases depending on the concentration and size of the magnetite particles in the filler.

\section{REFERENCES}

[1] B. D. Agarwal and L. J. Broutman, "Analysis and performance of fiber composites Second edition.” John Wiley \& Sons, 1990. Available: URL

[2] V. Chaudhary, A. K. Rajput, and P. K. Bajpai, "Effect of Particulate Filler on Mechanical Properties of Polyester based Composites," Mater. Today Proc., vol. 4, no. 9, pp. 9893-9897, 2017.

https://doi.org/10.1016/j.matpr.2017.06.289

[3] M. D. Kiran, H. K. Govindaraju, T. Jayaraju, and N. Kumar, "Review-Effect of Fillers on Mechanical Properties of Polymer Matrix Composites," Mater. Today Proc., vol. 5, no. 10, pp. 22421-22424, 2018. https://doi.org/10.1016/j.matpr.2018.06.611

[4] R. Khorshidi and A. Hassani, "Comparative analysis between TOPSIS and PSI methods of materials selection to achieve a desirable combination of strength and workability in Al/SiC composite," Mater. Des., vol. 52, , pp. 999-1010, Dec. 2013. https://doi.org/10.1016/j.matdes.2013.06.011

[5] C. P. Wong and R. S. Bollampally, "Thermal conductivity, elastic modulus, and coefficient of thermal expansion of polymer composites filled with ceramic particles for electronic packaging," J. Appl. Polym. Sci., vol. 74, no. 14, pp. 3396-3403, Oct. 1999. https://doi.org/10.1002/(SICI)10974628(19991227)74:14<3396::AIDAPP13>3.0.CO;2-3

[6] G. Farzi, M. Lezgy-Nazargah, A. Imani, M. Eidi, and M. Darabi, "Mechanical , thermal and microstructural properties of epoxy-OAT composites," Constr. Build. Mater., vol. 197, pp. 12-20, Feb. 2019.

https://doi.org/10.1016/j.conbuildmat.2018.11 .202

[7] T. Ji, Y. Feng, M. Qin, and W. Feng, "Thermal conducting properties of aligned carbon nanotubes and their polymer composites," Compos. Part A Appl. Sci. Manuf., vol. 91, no. 1, pp. 351-369, Dec. 2016.

https://doi.org/10.1016/j.compositesa.2016.10. $\underline{009}$

[8] S. Mishra and N. G. Shimpi, "Comparison of nano $\mathrm{CaCO} 3$ and flyash filled with styrene butadiene rubber on mechanical and thermal properties," J. Sci. Ind. Res., vol. 64, pp. 744751, Oct. 2005. Available: URL

[9] Y. M. De Moraes et al., "Mechanical behavior of mallow fabric reinforced polyester matrix composites," J. Mater. Res. Technol., vol. 7, no. 4, pp. 515-519, Oct. 2018.

https://doi.org/10.1016/j.jmrt.2018.02.013

[10] G. O. Glória et al., "Tensile strength of polyester composites reinforced with PALF," J. Mater. Res. Technol., vol. 6, no. 4, pp. 401405, Oct. 2017.

https://doi.org/10.1016/j.jmrt.2017.08.006

[11] A. O. Garzón Posada, F. Fajardo Tolosa, D. A. Landínez Téllez, J. Roa Rojas, and G. Peña Rodríguez, "Synthesis, Electrical, Structural and Morphological Characterization of a Composite Material Based on Powdered Magnetite and High Density," Rev. la Acad. Colomb. Ciencias Exactas, Físicas y Nat., vol. 37, pp. 57-61, Sep. 2017. Available: URL

[12] L. A. Lara González, "Efecto De La Degradación Por Inmersión En Acido Nítrico Sobre Las Propiedades De Un Poliéster Reforzado Con Fibras De Vidrio," Ing. Investig. y Desarro., vol. 10, no. 1, pp. 64-70, Jan. 2010. Available en: URL

[13] Z. Y. Shnean, "Mechanical and Physical Properties of High Density Polyethylene Filled With Carbon Black and Titanium Dioxide," Diyala J. Eng. Sci., vol. 5, no. 1, pp. 147-159, 2012 Disponible en: URL

[14] Kutz, M., Applied Plastics Engineering Handbook: Processing, Materials, and Applications, Elsevier, 2011. Available: URL 
Optimization of the Tensile Properties of Polymeric Matrix Composites Reinforced with Magnetite Particles by Experimental Design

[15] C. Ruddy, E. Ahearne, and G. Byrne, "A review of magnetorheological elastomers: properties and applications," Advanced Manufacturing Science (AMS) Research. 2012. Available: URL

[16] Z. Varga, G. Filipcsei, and M. Zrínyi, "Magnetic field sensitive functional elastomers with tuneable elastic modulus," Polymer, vol. 47, no. 1, pp. 227-233, Jan. 2006.

https://doi.org/10.1016/j.polymer.2005.10.139

[17] A. O. Garzón Posada, D. A. Landínez Téllez, J. Roa Rojas, and J. Ramos Barrado, "Materiales compuestos de matriz polimérica usados para el blindaje de interferencia electromagnética," Cienc. $\quad$ Ing. Neogranadina, vol. 27, no. 1, pp. 5-26, Jan. 2017. https://doi.org/10.18359/rcin.1917

[18] L. A. Lara, D. L. Mancipe, Y. Pineda, J. J. Moreno, and G. Peña-Rodríguez, "Design and characterization of a magneto-dielectric composite in high frequency with aligned magnetite powders," in Journal of Physics: Conference Series, Volume 1386, 5th International Meeting for Researchers in Materials and Plasma Technology (5th IMRMPT), Cucuta, 2019. https://doi.org/10.1088/17426596/1386/1/012103

[19] O. Philippova, A. Barabanova, V. Molchanov, and A. Khokhlov, "Magnetic polymer beads: Recent trends and developments in synthetic design and applications," Eur. Polym. J., vol. 47, no. 4, pp. 542-559, Apr. 2011. https://doi.org/10.1016/j.eurpolymj.2010.11.0 $\underline{06}$

[20] F. E. Salinas Tacumá, D. A. Landinez Téllez, A. O. Garzón Posada, and J. Roa Rojas, "Caracterización magnética de material compuesto con matriz de resina epoxi y llanta en desuso reforzado con magnetita en diferentes proporciones," TecnoLógicas, vol. 22 , no. 44, pp. 81-95, Jan. 2019. https://doi.org/10.22430/22565337.999

[21] D. C. Montgomery, "Diseño y análisis de experimentos," 2a ed., Limusa Wiley, 2010.

[22] V. K. Vankanti and V. Ganta, "Optimization of process parameters in drilling of GFRP composite using Taguchi method," J. Mater. Res. Technol., vol. 3, no. 1, pp. 35-41, Jan. 2014.

https://doi.org/10.1016/j.jmrt.2013.10.007

[23] I. L. Ngo, S. Jeon, and C. Byon, "Thermal conductivity of transparent and flexible polymers containing fillers: A literature review," Int. J. Heat Mass Transf., vol. 98, pp. 219-226 Jul. 2016. https://doi.org/10.1016/j.ijheatmasstransfer.2 $\underline{016.02 .082}$
[24] A. R. J. Hussain, A. A. Alahyari, S. A. Eastman, C. Thibaud-Erkey, S. Johnston, and M. J. Sobkowicz, "Review of polymers for heat exchanger applications: Factors concerning thermal conductivity," Appl. Therm. Eng., vol. 113, pp. 1118-1127, Feb. 2017.

https://doi.org/10.1016/j.applthermaleng.201 6.11 .041

[25] B. Weidenfeller, M. Höfer, and F. R. Schilling, "Thermal conductivity, thermal diffusivity, and specific heat capacity of particle filled polypropylene," Compos. Part A Appl. Sci. Manuf., vol. 35, no. 4, pp. 423429, Apr. 2004. https://doi.org/10.1016/j.compositesa.2003.11. $\underline{005}$

[26] L. Á. Lara González, G. Peña-Rodríguez, and Y. P. Triana, "Effective thermal properties of a magnetite-polyester composite conformed in the presence of a constant magnetic field," AIMS Mater. Sci., vol. 6, no. 4, pp. 549-558, Jul. 2019.

https://doi.org/10.3934/matersci.2019.4.549

[27] B. Torres, A. García-Escorial, J. Ibáñez, and M. Lieblich, "Propiedades mecánicas de materiales compuestos de matriz de aluminio reforzados con intermetálicos," Rev. Metal., vol. 37, no. 2, pp. 225-229, 2001. https://doi.org/10.3989/revmetalm.2001.v37.i $\underline{2.470}$

[28] B. Torres, A. García-Escorial, J. Ibáñez, and M. Lieblich, "Propiedades mecánicas de materiales compuestos de matriz de aluminio reforzados con intermetálicos," Rev. Metal., vol. 37, no. 2, pp. 225-229, 2001. Available: URL

[29] S. D. Thoppul, J. Finegan, and R. F. Gibson, "Mechanics of mechanically fastened joints in polymer-matrix composite structures - A review," Compos. Sci. Technol., vol. 69, no. 3-4, pp. 301-329, Mar. 2009. https://doi.org/10.1016/j.compscitech.2008.09. $\underline{037}$

[30] M. S. Boon and M. Mariatti, "Optimization of magnetic and dielectric properties of surfacetreated magnetite-filled epoxy composites by factorial design," J. Magn. Magn. Mater., vol. 355, pp. 319-324, Apr. 2014. https://doi.org/10.1016/j.jmmm.2013.12.002

\section{AUTHOR CONTRIBUTIONS}

(D) 1 Elaborated the introduction and the methodological development; designed the methodology for the elaboration of the 
compounds and participated in the fabrication of the composite materials; developed the experimental design incorporating the data in the computational model, and interpreted the results.

(D) 2 Contributed to the elaboration of the experimental design in the mechanical tests of the composite material, the graphic design and the preparation of the results.

(D) 3 Reviewed the experimental design and the results of the mechanical tests.
D 4 Contributed to the literature review, analysis and adjustment of the response model.

(D) 5 Contributed to the definition of the factors, executed the experimental design and the validation process with statistical tools.

All the authors participated in the construction of the document, in the writing process and in the presentation of results and elaboration of the conclusion. 